\title{
SOCIO-ECONOMIC EMPOWERMENT OF COMMUNITIES BY GRASSROOTS ORGANIZATIONS: THE CASE OF THE HARAMBEE SELF HELP GROUPS IN KENYA
}

RICHARD MUKO OCHANDA ${ }^{1}$

\begin{abstract}
This paper contributes to the discourse on grassroots organizations by providing details of research on traditional Harambee Self Help Groups (SHG) in Kenya in the light of social enterprise and third sector discourses. Data for this study were provided by the provincial administration of Riruta Location in Nairobi, Kenya. The location archives were comprised of self-help group registration forms, constitutions, details of dispute processes, correspondence, proposals and minutes.

The study found that increases in SHG resource mobilization activities, organizational meetings, governmental recognition (registration), membership and village outreach had a significant positive influence on the number of economic empowerment activities. Decreases in networking and increases in challenges faced by the SHGs had a negative influence on their activity.

This study attempts to equate the Harambee SHGs with social enterprises, studies their entrepreneurial dynamic within the Kenyan third sector and examines their historical and current contribution to the country.
\end{abstract}

Keywords Social Enterprises, Third Sector, Harambee, Self Help Groups, Community-Based Organizations.

JEL Classification: I138 and L26

1 The author is a Ph.D. Candidate at the University of Trento, School of Local Development, Italy and is also affiliated to Euricse, whose support made this study possible. Much gratitude is given to Prof. Carlo Borzaga, Dr. Ermanno Tortia of Trento and the anonymous referees. The author also thanks Chief James Ndichu and Evans Gacobi for availing to him the Riruta Locational Data. Address: KARDS Development Consultants, P. O. Box 16139, 00100 Nairobi, Kenya; e-mail: richomuko@gmail.com 


\section{INTRODUCTION}

Grassroots organizations are becoming important social economic empowerment actors for marginalized populations in developing countries. They play an important role in promoting democracy, human development and equitable distribution (Ngau, 1987). They also provide a space for a diversified range of actors with different capacities and interests to empower their communities at large. While it is important to recognize that the grassroots movement may be diverse and complex, there is heterogeneity in the membership of groups, in the nature of their tenure (which could be short or long term) and whether they address a single or a broader range of issues (Male, 1976).

Though their role in a globalized world seems to be changing, grassroots organizations are first and foremost community-based. They represent vulnerable groups who are severely affected in terms of the material available to them, their vulnerability to global and national policies and economic fluctuations (Bhatliwala, 2002). The term grassroots does not allow for differentiation between the latent differences amongst members in terms of resources, skills, education and whether members are directly or indirectly affected by the problem being addressed. These differences have a bearing in terms of participation and the benefits which accrue to each member within a group.

The contributions made by grassroots organizations in providing services to the marginalized, promoting human welfare and in promoting the growth of the third sector in the world cannot be overemphasized. These contributions enhance human development within their local communities in terms of skill building, economic empowerment and enhancing quality of life (Matanga, 2000). Some of the applied areas the grassroots groups work in include poverty eradication, policy advocacy, provision of housing, gender empowerment, peace building, disaster mitigation, water and sanitation, environment, and so on. They thus play important roles at the micro-community level. Their microlevel activities have positive ripple effects at the macro level of the economy. They promote the empowerment of the periphery by making individuals full participants in the socio-economic development space, rather than only being recipients of development ideas from the core (UNDP, 1990).

The contribution of the grassroots movements in Sub Saharan Africa to human development is quite important. This study helps to identify these contributions by detailing the socio-economic contributions of the Harambee Self Help movement in Kenya in the light of the growing third sector and social enterprise discourses. The objectives of the study were: 
- To study the socio-economic empowerment activities of the Harambee self-help movement in Kenya;

- To examine the entrepreneurial dynamic of the Harambee self-help groups; and,

- To define the role being played by the Harambee self-help groups in building-up a vibrant third sector in Kenya.

The rest of the study is organized as follows: The following section gives a detailed history and discussion of the Harambee self-help movement in Kenya. The third chapter presents the methodology used in the study, while the fourth presents a descriptive and econometric analysis of the data and incorporates discussions of the findings. The fifth chapter concludes.

\section{THE HARAMBEE GRASSROOTS MOVEMENT IN KENYA}

Though the Harambee movement received its original impetus from the elite and government policies (Republic of Kenya, 1965), its growth and diffusion is mainly associated with government failure to address welfare gaps which became a source of frustration to communities (Ngau, 1987). Such frustration, accompanied by failure to attract state attention, led to the emergence of organized local efforts to meet some of the needs which arose (Mbithi \& Rasmusson, 1977). The most vivid exposition of the Harambee movement involved fundraising activities which dominated the academic literature on the topic from the 1970's to date (Transparency International Kenya, 2001).

Despite the fact that the fundraising aspect of the movement did much to complement government and communities' local development efforts, it was marred by several weaknesses which ranged from political patronization and corruption to stifling of the self-help spirit (Waiguru 2002). These weaknesses (and many others) led to a conflict between the grassroots and the elite leaders of the movement as far as choosing projects was concerned. The elite/leaders fostered projects that ran counter to the ideals of self-help while people at the grassroots level created small projects that responded to their own local needs (Ngau 1987). This conflict, in the long run, caused disillusionment with the mass mobilization aspect of the Harambee movement, leading to the formation of community grassroots self-help organizations. The formation of the self-help groups signified that communities were choosing to withdraw from the conventional Harambee system and wanted to be in charge of their own lives in order to develop small projects which they would be in control of. 
In time, therefore, the Harambee self-help movement came to exemplify a grassroots organization on one hand and a mass political mobilization movement on the other. Hence, Harambee became a very broad term which covers three dimensions of self-help. These dimensions are:

a) Fundraising: Fundraising has two components. It either entails mammoth fundraising campaigns for the government or community projects or it entails small scale fund raising campaigns for mutual assistance purposes (Ombudo 1986);

b) Community action: This describes community-organized practical tasks geared towards immediate or long term improvements of communities. Examples of community action include building schools or gabions or addressing security concerns (Ouma 1980);

c) Small self-help projects: These are community-based organizations or groups formed on a cooperative basis for the purpose of mutual assistance. They address particular community-based challenges (Godfrey-Mutiso 1973; Male 1976).

From the above three categories, therefore, the Harambee movement's important contribution was the building of self-reliant communities, the use of local capacity and resources and the promotion of community-organized action aimed at addressing individual and mutual challenges.

There are two main resource mobilization approaches in the Harambee movement; the first being a mass resource mobilization approach for community benefit (Godfrey - Mutiso 1973); the other is a cooperative selfhelp group approach (Ngau 1987). The mass resource mobilization approach has always dominated the literature and is the most visible aspect of the Harambee movement. The self-help groups, despite constituting the bulk of the movement's activities, remain quite invisible.

The Harambee self-help movement is regarded as a unique Kenyan institution, rooted in history and in the African tradition of mutual responsibility (Chelogoy - Anyango - Odembo, 2004). In the traditional communities of Kenya, people pooled efforts for activities which required intensive inputs of labor, such as hut building, clearing virgin land and harvesting (Ombudo 1986). During the 1950s to 1960s, Harambee was used as a tool of political mobilization against colonialism. In post-independence Kenya, Harambee, or the self-help and/or mutual help spirit, became a critical strategy for local development (Republic of Kenya, 1965; 2009a).

There is a controversy about the origin of the term Harambee. According to Ombudo (1986), Harambee is a Bantu word which has its origins in the word Halambee. This word was used by porters in Kenyan coastal towns before it diffused throughout the country. Literally, it meant "Let us all pull together". 
Martin (1990) and Sobania (2003) attribute the term to Swahili's working gang cry, which is an amalgam of two words "aaaa" which means "ready" and "mbee" meaning "push". According to Transparency International (2001), the word Harambee may have possibly originated from a colloquialism of Indian origin which translates to 'pooling effort'. The words entered Kenya via members of the Indian community who were employed in construction of the Kenya-Uganda railway during the colonial period. The origin of the word is two words: "Hare" meaning Praise and "Ambe" meaning one of the Hindu Gods associated with wealth and good health.

Despite the controversy about its origins, Harambee is considered to be a way of life in Kenya (Transparency International 2001) and is entrenched in local traditions and customs (Republic of Kenya 1979). It is also a unique development tool and an integral element of Kenyan Nationalism. It was designed to create local resources in order to combat illiteracy, disease and poverty (Republic of Kenya 1965). Harambee as a strategy was first used in the 1920s to raise funds to send the first President of Kenya to England to petition the British Government for the return of African lands (Transparency International Kenya 2001). In the 1950s it was mainly used as a mass mobilization slogan against colonialism. Following independence, Harambee was integrated into the national development strategy as a form of cost sharing between the government and the public (Republic of Kenya 1964a).

Harambee symbolizes both the micro and macro self-help aspects of local development that incorporate complicated dynamics of grassroots and elite interests (Ngau 1987). In time it came to symbolize self-help initiatives geared towards community development, mutual assistance and thus came to epitomize a welfare instrument (Wallis 1976). As a strategy for community development, it was used to raise funds from community members and other stakeholders in order to support a community or governmental initiative (Mbithi-Rasmusson 1977). As a mutual assistance tool, it entailed the formation of self-help groups amongst the grassroots constituency which would be of service to the individual, the group and the community. These groups were mainly embraced by women who used them to raise money for their group members on a merry-go round basis, or through the pursuit of a common enterprise (Coppock, et al. 2006).

The self-help group members would help each other buy goods, such as house furniture or roofing materials, they would boost a member's capital so they could pursue income-generating activities or they might address a problem within their community, such as education or child care, etc. (Nyaga 1986). As welfare instruments, the self-help groups started to address problems which affected individuals. They established small projects using 
resources which were mobilized locally within the group or from the group's networks in order to respond to specific needs (Hamer 1981). Harambee selfhelp groups hence assumed an important role in delivering welfare benefits to vulnerable sections of society.

\section{THE EVOLUTION OF THE HARAMBEE SELF HELP MOVEMENT}

The self-help groups faced numerous challenges in their evolution. Government administrative and community development staff impeded their growth during the 1960s to 1990s. In an effort to retain strict control of the country the government ensured that only a very small number of self-helps were registered in the 1980s (Wallis 1990). This situation worsened after a failed attempt at a coup d'état in 1982 (Branch - Cheeseman, 2007) after which it became a mandate of the administration to either approve or disapprove projects for registration and government funding. As such, administrative bureaucracies became a hindrance and started to impede small-scale local initiatives. This bureacracy created resentment and caused members to withdraw from grassroots organizations. Hence many groups were started informally and existed without formal approval (Wallis 1976).

In the 1970's it was felt that the Harambee projects which existed had been politicized and that the autonomy of the self-help groups was becoming detrimental to the establishment (Ngau 1987). Stringent requirements for project approval were therefore introduced and bureaucracy was strengthened. Harambee activities were hence placed under the direct control of the community development division of the Ministry of Cooperatives and Social Services. This heavy regulatory regime created difficulties for local and grassroots development initiatives (Transparency International 2001).

Since gaining control of the self-help groups was a great gain to the bureaucracy, the mass mobilization aspect of the Harambee floated in the space between the politicians, community development staff and the provincial administration. The occasional competition for patronization of the fundraising aspects of Harambees by executives had negative repercussions on the grassroots (Matanga 2000). These elite competitors issued conflicting directives to members which contributed to a loss of enthusiasm with Harambee mass mobilization. The disillusionment with Harambee mass mobilization took various forms, such as apathy, withholding voluntary efforts and refusal to participate (Ngau 1987). Individuals and groups chose to withdraw or refuse to participate in conventional Harambee activities and 
instead chose to engage in small-scale mutual self-help activity. Preferences for grassroots self-help groups indicated that people wanted greater control over their own lives.

Self-help groups started becoming more visible and pronounced community actors in Kenya after the turn of the millennium. They became leading players in addressing community-based concerns such as children's rights issues (Koinonia Community 2006), youth issues, women's issues, working with marginalized communities, education and economic empowerment of the poor (Ochanda - Akinyi - Mungai, 2009; Republic of Kenya 2009i). This visibility is attributed to the widening democratic space in Kenya and the desire of the masses to establish projects which were manageable.

Despite their positive role in fighting social exclusion, the government made little attempt to give the Harambee self-help groups proper legal structure over the years (Republic of Kenya 2009a). This lack of recognition has denied the country full-blown community oriented social innovation, stifled the full participation of the third sector in development and limited the full potentiality of self-help groups. An inappropriate legislative regime also contributes to the opportunism of self-help members and curbs their ability to pursue diversified resource mobilization strategies.

Marred by many challenges, the self-help groups joined together in 2005 to form the CBO consortium of Kenya, a national body which could champion their interests and increase their visibility. This body is made up of voluntary self-help groups who register and subscribe to it. The CBO Consortium of Kenya is designed to build the capacity of members, become a voice for selfhelp groups in Kenya and facilitate advocacy and resource mobilization.

\section{STUDY METHODOLOGY}

The data for this study was made available by the provincial administration offices of the Riruta Location. The author was allowed access to these archives from May to August 2010. The locational archives used for this study date from January 1984 to August 2010. During this time a total of approximately 524 self help groups were registered in Riruta Location. The archival records indicated that most groups' operations were located in the different localities of Riruta while a few others, though registered in Riruta, were operating outside the location.

The archival materials used were comprised of the self-help groups' registration forms, constitutions, proposals, official communications, dispute resolutions processes, reports of their activities and resource mobilization 
activities and minutes. An instrument was developed to capture the data in a standardized format. The data collected included demographic information about the self-help groups, their objectives, work carried out and the nature of their resource mobilization activities. From the archives it was possible to capture data about the challenges and successes of the self-help groups.

The choice of Riruta as a location for this study was based on its unique nature. The area has three typologies of residential areas: slum areas where the urban poor reside; a middle income area where those considered to be earning a medium income reside; and, lastly, a peri-urban area which has some resemblance to rural community areas.

It is important to note that while this study was taking place, Kenya adopted a new constitution which will change the entire administrative structure of the country. The present provincial structure with its 8 provinces and 140 districts is slowly being transformed into 47 counties (Republic of Kenya 2010). The transformation process will be accelerated after the elections of 2013. The analysis described in this paper, however, utilized the original provincial structure.

\section{DESCRIPTIVE STATISTICS}

Table 1: Dagoretti Constituency Population

\begin{tabular}{l|c|c} 
Place & Population & \% Distribution \\
\hline Kawangware Location & 86,824 & 36.16 \\
\hline Riruta Location & 65,958 & 27.47 \\
\hline Kenyatta/Golf Course Location & 30,253 & 12.60 \\
\hline Uthiru/Ruthimitu Location & 23,016 & 9.59 \\
\hline Waithaka Location & 19,937 & 30. aug \\
\hline Mutuini Location & 14,521 & $05 . j u ́ n$ \\
\hline Dagoretti Constituency & 240,081 & 100
\end{tabular}

Source: Kenya Bureau of Statistics

Table 1 illustrates the population distribution of seven locations within the Dagorreti District including Riruta which has a population of 65,958 people. Dagoretti is a district in Nairobi province in Kenya with a population of 240,081. The population in the other locations of the district is distributed as follows: Kawangware: 86,824 , Kenyatta/Golf Course: 30,253, Uthiru/ 
Ruthimitu: 23,016, Waithaka: 19,937 and, lastly, Mutuini, with 14,521 people. The entire District is located within the area of Nairobi City Council. The Dagoretti District covers a total area of $39 \mathrm{~km}^{2}$.

Table 2: Self-help group creation and registration by year

\begin{tabular}{l|c|c} 
Year of creation & Groups created & Groups registered \\
\hline $1984-1990$ & 2 & 2 \\
\hline $1991-1995$ & 2 & 24 \\
\hline $1996-2000$ & 6 & 193 \\
\hline $2001-2005$ & 161 & 299 \\
\hline $2006-2010$ & 352 & 523
\end{tabular}

Source: Kenya Bureau of Statistics

Fewer self-help groups were created between the 1980s and the year 2000 (data shows that only 2 groups were created in the period between 19841990). Only five groups were created between 1991-1995 and only 24 groups between 1996-2000. There was a phenomenal increase in the creation of selfhelp groups from 2001 with 193 groups created in the period between 20012005 alone. In a period of just five years, beginning in 2001, six times more self-help groups were created than in the previous decade. Between 20062010 an additional 299 self-help groups were created.

Many SHGs were hence created and registered from 2000-2010. A total of 492 groups were created during the period, while 513 groups were registered. Some of the groups registered at this time had been created during the previous decade and were operating informally. On average, between 2001-2010, approximately 49 groups were being created annually and 51 organizations were being registered.

Despite its positive impact, the registration process however did have many latent weaknesses. Self-help groups that registered received a certificate but were not recognized in law as legal entities. Hence they could not enter into binding contracts and this lost them certain opportunities. However, the process helped them to be recognized in the community, open bank accounts, conduct business and conduct resource mobilization activities. 
Table 3: Distribution of economic empowerment activities

\begin{tabular}{l|c|c} 
Number of economic empowerment activities pursued & Frequency & Percentage \\
\hline 0 economic empowerment activities & 210 & 40.15 \\
\hline 1 economic empowerment activity & 163 & 31.17 \\
\hline 2 economic empowerment activities & 109 & 20.84 \\
\hline 3 economic empowerment activities & 32 & $12 . j u ́ n$ \\
\hline 4 economic empowerment activities & 9 & 1.72 \\
\hline Total & 523 & 100
\end{tabular}

Source: Author's own calculations

Two hundred and ten groups (or $40.15 \%$ of the SHGs) did not implement any economic empowerment activity. Of those which did implement some form of economic empowerment activities, 163 undertook one activity, 109 undertook two activities, 32 undertook three activities and 9 undertook four activities. Economic activities included job creation, business and investments, fundraising, transport, microfinance, house, plot and asset investment, farming and animal husbandry, production activities and the marketing and promotion of self-employment. Farming-related activities included the keeping of poultry, production of cereals and vegetables and fruit. Other farming activities included bee-keeping and growing mushrooms.

Producer activities included tailoring, food processing, carpentry, hair dressing, moulding, bead making, knitting, embroidery, mechanic and repair activities, welding, shoe making, producing sports items, carving and production of papier mache. Business activities on the other hand entailed capital seeding in the form of either financial or material assistance, group or individual investments, services such as water delivery, transportation or typing and printing services. Lastly, micro-finance activities included providing loans, savings, loans guarantees, revolving finance and communication with financial institutions.

Two hundred and sixteen groups implemented one social empowerment activity while 122 implemented two activities. 57 groups implemented at least three social empowerment activities, 19 implemented four, 5 implemented five and 1 group implemented seven social empowerment activities. In total there were 103 groups that did not implement any form of social empowerment activity. 
Table 4: Distribution of social empowerment activities

\begin{tabular}{l|c|c} 
Number of social empowerment activities pursued & Frequency & Percentage \\
\hline 0 social empowerment activities & 103 & 19.69 \\
\hline 1 social empowerment activity & 216 & 41.30 \\
\hline 2 social empowerment activities & 122 & 23.33 \\
\hline 3 social empowerment activities & 57 & 10.90 \\
\hline 4 social empowerment activities & 19 & 3.63 \\
\hline 5 social empowerment activities & 5 & 0.96 \\
\hline 7. social empowerment activities & 1 & 0.19 \\
\hline Total & 523 & 100
\end{tabular}

Source: Author's own calculations

Social empowerment activities are numerous and they include entertainment, performing arts, building toilets, care of minorities, care for victims of sexual violence, social insurance, school education and informal education. They also include HIV-related interventions, provision of social and community amenities, sports, youth empowerment, care of orphans and vulnerable children, gender-related work, assisting commercial sex workers, nutritional support, drug awareness, religious support, assisting the disabled and those with special needs, cultural activities, health and psychological counseling. Health activities include medication, advice about reproductive health, hygiene, family health and the prevention of sexually transmitted diseases. Gender-related work centered on providing advocacy about the legal, cultural and societal barriers that promote inequality and inequity between men and women. Social insurance entailed meeting special individual needs such as education, hospital bills, funeral costs, maternity expenses, and dowry and wedding expenses.

Table 5: Distribution support activities

\begin{tabular}{l|c|c} 
Number of support activities pursued & Frequency & Percentage \\
\hline 0 support activities & 325 & 62.14 \\
\hline 1 support activity & 148 & 28.30 \\
\hline 2 support activities & 41 & 7.84 \\
\hline 3 support activities & 9 & 1.72 \\
\hline Total & 523 & 100
\end{tabular}


'Support activities' were those activities that either had economic and social dimensions or were those that were hard to categorize into a single group. 325 self-help groups did not implement any support activity at all. 148 on the other hand implemented one support activity, 41 implemented two and 9 SHG's implemented three activities.

These support activities included material and financial support, disaster management, implementation of development projects, networking, peacebuilding, legal aid, improving security, environmental care, civic participation and improving access to water and community development. Water-related work entailed sinking boreholes, installing water-related equipment and actually delivering water to homesteads. Civic participation, on the other hand, entailed lobbying public administration about services and on human rights and policy and development issues. Lastly, community development entailed doing work to eradicate poverty, improve community infrastructure, mobilize communities around a particular concern and promote community voluntary work, as well as other forms of social work.

Table 6: Number of villages reached by the SHGS

\begin{tabular}{l|c|c} 
Number of villages reached & Frequency & Percentage \\
\hline 1 village & 303 & 57.85 \\
\hline 2 villages & 180 & 34.48 \\
\hline 3 villages & 23 & 4.41 \\
\hline 4 villages & 17 & 26. márc \\
\hline Total & 523 & 100
\end{tabular}

Source: Author's own calculations

$57.85 \%$ of self-help groups work within one village. $34.48 \%$ provide their services to two villages while $4.41 \%$ work in three villages and only $3.26 \%$ work in 4 villages. The fact that most SHGs were reported to be working within a single village shows the high level of local embeddedness of SHG members. The local nature of the services they provide give them the ability to understand deeply the problems faced by their communities and, in most cases, develop simple solutions that are inexpensive given the absence of other alternatives. On the other hand, because of resource deficiencies, their local solutions may not be totally optimal. 
Table 7: SHG networks

\begin{tabular}{l|c|c} 
Number of networks pursued & Frequency & Percentage \\
\hline 0 networks & 386 & 73.80 \\
\hline 1 Network & 76 & 14.53 \\
\hline 2 Networks & 46 & 8.80 \\
\hline 3 Networks & 14 & 2.68 \\
\hline 4 Networks & 1 & 0.19 \\
\hline Total & 523 & 100
\end{tabular}

Source: Author's own calculations

Self-help groups in Riruta are poor networkers. $73.80 \%$ were not actively developing any type of networking relationships. $14 \%$ are engaged in one type of network, $8.80 \%$ have two networks, $2.68 \%$ have three networks and only $0.19 \%$ have 4 networking relationships. The types of SHG networks are explored in Table 8 below.

Table 8: Types of networks pursued by the SHGS

\begin{tabular}{l|c|c} 
Types of networks pursued & Frequency & No Networks \\
\hline Collaboration with other SHGs & 48 & 475 \\
\hline Collaboration with a parent organization & 20 & 503 \\
\hline Collaborating with the government & 14 & 509 \\
\hline Collaborating with a financial institution & 55 & 468 \\
\hline Collaborations with professional individual/bodies & 5 & 518 \\
\hline Other types of collaborations & 72 & 451 \\
\hline Average & 35.67 & 487.33
\end{tabular}

Source: Author's own calculations

Networks that SHGs were engaged in were related to community development or the joining of community-organized events such as prayer meetings or linking with donors. Organizations involved in these types of activities were 72 in number (meaning that 451 were not engaged in such networks). 48 SHGs pursued active collaboration with other SHGs while 475 did not. The SHGs that pursued collaboration activities with financial institutions were 55 in number while 468 did not pursue these types of networking opportunities. Far fewer organizations sought to create or maintain networking relationships with the government or with professional bodies or individuals. 
Table 9: Total number of resource mobilization activities by SHGS

\begin{tabular}{l|c|c} 
Number of resource mobilization activities & Frequency & Percentage \\
\hline 0 activity & 2 & 0.38 \\
\hline 1 activity & 57 & 10.90 \\
\hline 2 activities & 27 & 16. máj \\
\hline 3 activities & 42 & 03. aug \\
\hline 4 activities & 63 & 05. dec \\
\hline 5 activities & 131 & 25. máj \\
\hline 6 activities & 164 & 31.36 \\
\hline 7 activities & 37 & $07 . j u ́ l$ \\
\hline Total & 523 & 100
\end{tabular}

Resource mobilization activities describe how the self-help groups raise the resources to finance their activities. Table 10 below explains these activities. 521 self-help groups undertook at least one resource mobilization activity and there were only 2 who indicated that they had no resource mobilization activities. The majority of SHGs either undertook 5 or 6 activities to capture resources to finance their activities. This shows that the SHGs in essence were pursuing a resource mix approach to their resource mobilization activities. This resource mix approach is an important characteristic of social enterprises. The resource dependency approach also considers that diversifying resources is good for organizational survival. Hence organizations which are able to attract resources have a greater chance of survival than those with little ability to do so.

Table 10: Type of SHG resource mobilization activity

\begin{tabular}{l|c|c} 
Type of resource mobilization activity & Frequency & Percentage \\
\hline Member resources & 502 & 95.98 \\
\hline Business resources & 341 & 65.20 \\
\hline Equity resources & 60 & 11.47 \\
\hline Loan resources & 390 & 74.57 \\
\hline Savings resources & 427 & 81.80 \\
\hline Transaction charges resources & 339 & 64.94 \\
\hline Community resources & 327 & 62.64 \\
\hline Donor resources & 178 & márc.34
\end{tabular}

Source: Author's own calculations 
Most SHGs collect resources through member contributions (95.98\%). Members usually contribute to the SHG according to their abilities. In doing so they support the critical initial and recurrent capitalization operations of the SHGs. Members' savings are important to $81.80 \%$ of the SHGs. Though there is an indication that such savings are used to fund SHG activities, the activities they fund mainly involve providing loans to members, thus such activities do not deplete the pool of group savings. Loans, too, are important resources for SHGs (74.57\%) and may be advanced either by other financial institutions to the SHGs or by the group itself to members. $65.20 \%$ of the SHGs have business projects which help to generate the required resources. Other resource mobilization strategies include transaction charges $(64.94 \%)$, contributions from the community $(62.64 \%)$, donor resources $(34.03 \%)$ and lastly, equity resources (11.47\%). Accordingly, it can be seen that most resources seem to be generated from entrepreneurial activities and from member contributions.

Table 11: Challenges faced by the SHGS

\begin{tabular}{l|c|c} 
Number of challenges & Frequency/523 & Percentage \\
\hline Financial challenges & 518 & 99 \\
\hline Professional challenges & 188 & 36 \\
\hline Competition challenges & 167 & 32 \\
\hline Information and communication challenges & 141 & 27 \\
\hline Sustainability challenges & 136 & 26 \\
\hline Human capital challenges & 110 & 21 \\
\hline Legal challenges & 68 & 13
\end{tabular}

Source: Author's own calculations

Ninety nine percent of the groups reported that they faced challenges related to their lack of financial and material resources. Accordingly, there is a great need to foster better collaborative and networking practices to deal with the challenge of funding uncertainty and the lack of important facilities and equipment which can impede service effectiveness. In various cases the external funding of groups with weaker leadership had a negative effect on the group's social capital. $36 \%$ of the SHGs faced professional challenges which manifested itself in poor transparency and accountability. Other problems included nepotism and poor gender mainstreaming. 32\% of the groups reported that they had challenges facing off competition from better organized and more efficient self-help groups. $27 \%$ of the groups also 
experienced information and communication challenges. The inability to access information and communicate appropriately had negative repercussions on the competitiveness of the groups. $26 \%$ experienced sustainability challenges. This indicates that lack of resources was so acute that it was capable of negatively affecting the group's ability to sustain the impacts of its projects in the future. Other challenges SHGs faced were human capital related $(21 \%)$ and legal $(13 \%)$.

On the beneficiary side there were also a number of challenges to be overcome, especially for people with HIV, drug addicts, commercial sex workers, street children, sexual minorities and others with special needs. These populations were subjects of stigma. Fighting this stigma proved to be an uphill task as there were no or limited resources available to help redress the problem. Awareness-raising work was at times pursued at the expense of other services to beneficiaries. There were other factors that impeded effective assistance being given to some beneficiaries who required special attention or treatment. These factors were the poor discipline of said beneficiaries and/ or their denial of their status, as described above, or ignorance. There were also other factors which impeded effective provision of help, such as religious and cultural traditionalist movements that either promoted faith healing to their followers or scoffed at modern scientific approaches to the treatment of disease.

\section{ECONOMETRIC MODEL}

Table 12: Description of Variables

\begin{tabular}{c|l} 
Variable name & Variable label \\
\hline Ecomp & Economic empowerment activities \\
\hline Toremo & Total resource mobilization activities \\
\hline Boameet & Number of board meetings \\
\hline Orgmeet & Number of organizational meetings \\
\hline Regyr & Year of SHG registration \\
\hline Totmem & Total SHG members \\
\hline Villoutr & Total service outreach villages \\
\hline Network & Total SHG networks \\
\hline Totchals & Total number of challenges
\end{tabular}


A number of variables are listed in Table 12. The dependent variable is economic empowerment activities (these economic empowerment activities were explained in Table 3). The dependent variable has count characteristics. Other properties of these variables are further explained in Table 13 below. The explanatory variables are the following: the total number of resource mobilization activities undertaken by an SHG, the total number of management committees and members meetings, the year of SHG registration, total membership in the SHG, the number of villages being served, the total number of networking partners and the total number of challenges experienced by the SHG.

Table 13: Summary distribution of total economic empowerment activities

\begin{tabular}{c|c|c|c|c} 
Variable & obs & mean & Variance & \\
\hline $1 \%$ & 0 & 0 & & \\
\hline $5 \%$ & 0 & 0 & & \\
\hline $10 \%$ & 0 & 0 & & 523 \\
\hline $25 \%$ & 0 & 0 & Obs & 523 \\
\hline & & & Sum of WGT & .9808795 \\
\hline $50 \%$ & 1 & & Mean & 1.005549 \\
\hline & & Largest & Std deviation & \\
\hline $75 \%$ & 2 & 4 & Variance & 1.011128 \\
\hline $90 \%$ & 3 & 4 & Skewness & .8077244 \\
\hline $95 \%$ & 4 & 4 & Kurtosis & 2.988008 \\
\hline $99 \%$ & & 4 & &
\end{tabular}

The minimum occurrence of the variable is 0 counts while the maximum is 4. This means that in the case that a self-help group undertakes no economic empowerment activity we allocate a 0 count to it. Alternatively, it could be involved in 1 or 2 or 3 or 4 economic empowerment activities. The existence of any number of economic empowerment activities in one SHG is independent of these activities in other SHGs. Given that the independent variable displays a count characteristic, the data set could be a candidate for the use of either Poisson Regression or Negative Binomial Regression.

According to Table 13, the variance is larger than the mean. It is, however, within the limits of equi-dispersion since the difference between the mean and the variance is 0.030249 . The variance is hence not greater than might be expected in a Poisson distribution (making the Poisson regression procedure 
more appropriate than the Negative Binomial Regression). A Negative Binomial Regression would suffice if the variance was much greater than the mean and displayed the tendency to over-dispersion.

The data for the dependent variable are strongly skewed to the right and are not continuous, indicating that a linear regression analysis would be inappropriate (in such cases it can give results that are inefficient, inconsistent and biased). For such variables, models such as Poisson regression or the negative binomial regression models are appropriate. In a Poisson regression, the probability of a count is determined by a Poisson distribution, where the mean of the distribution is a function of the independent variables. This model has the defining characteristic that the conditional mean of the outcome is equal to the conditional mean of the variance. A critical assumption of a Poisson process is that events are independent.

\section{THE REGRESSION MODEL}

We hence use the Poisson regression model, where the number of event, $y$ , has a Poison distribution with a conditional mean that depends on an event's characteristics. The regression model is hence expressed as:

$$
\lambda_{i}=E\left(y_{i} \mid x_{i}\right)=\exp \left(x_{i} \beta\right) .
$$

The exponential of $x_{i} \beta$ forces the expected $\lambda$ to be positive, as required for the Poisson distribution.

Since the model is nonlinear the value of the marginal effect depends on both the coefficient for $x_{k}$ and $E(y \mid x)$. The larger the value of $E(y \mid x)$, the larger the rate of change in $E(y \mid x)$. Further, since $E(y \mid x)$ depends on the value of all dependent variables, the value of the marginal effect depends on the level of all the variables. Often, the marginal effect is computed using the mean of all variables. The marginal effect is the partial derivative of $E(y \mid x)$ with respect to $x_{k}$ and is computed using the chain rule as follows:

$$
\frac{\partial E(y \mid x)}{\partial x_{k}}=\frac{\partial \exp (x \beta)}{\partial x \beta} \frac{\partial x \beta}{\partial x_{k}}=\exp (x \beta) \beta_{k}=E(y \mid x) \beta_{k}
$$


Table 14: Poisson Regression Model Outputs for Economic Empowerment Activities

\begin{tabular}{c|c|c|c} 
Variable & Coef & Std Err & Significance \\
\hline Toremo & .3363773 & .0962254 & 0.000 \\
\hline Boamee & .0312306 & .0203367 & 0.125 \\
\hline Orgmeet & .0006095 & .00468 & 0.896 \\
\hline Regyr & .0544732 & .0307126 & 0.076 \\
\hline Totmem & .0004188 & .0065446 & 0.949 \\
\hline Villoutr & .2075913 & .1937157 & 0.284 \\
\hline Network & -.2121747 & .1654673 & 0.200 \\
\hline Totchals & -.1412141 & .0786354 & 0.073 \\
\hline cons & -111.0878 & 61.52863 & 0.071
\end{tabular}

A Poisson model was estimated using the basic variables. The outputs are illustrated in Table 14. We proceeded to compute the marginal effects of the Poisson model. As noted above, the value of the marginal effect in a Poisson Distribution depends on the value of all independent variables. The outputs of the marginal effect computations of the model are presented in Table 15.

Table 15: Poisson Regression Model marginal effects outputs for economic empowerment activities

\begin{tabular}{c|c|c|c} 
Variable & $\mathrm{dy} / \mathrm{dx}$ & Std Err & Significance \\
\hline Toremo & .3051293 & .08129 & 0.000 \\
\hline Boamee & .0283294 & .0183 & 0.122 \\
\hline Orgmeet & .0005529 & .02756 & 0.896 \\
\hline Regyr & .0494129 & .02756 & 0.073 \\
\hline Totmem & .0003799 & .00594 & 0.949 \\
\hline Villoutr & .188307 & .17469 & 0.281 \\
\hline Network & -.1924647 & .14896 & 0.196 \\
\hline Totchals & -.128096 & .07084 & 0.071 \\
\hline cons & & &
\end{tabular}

According to the results of marginal effects presented in Table 15, a unit change in resource mobilization activities has a positive effect on the changes that can be expected in the number of economic empowerment activities. The existence of successful resource mobilization activities is important in predicting whether or not a self-help group will take on more 
economic empowerment activities. It also enhances organizational survival. It appears that self-help groups could benefit by pursuing a mix of strategies regarding their resources. They could raise resources from government sources, communities, business activities or local and international funding organizations.

There is some evidence that resource mobilization is a great challenge and that SHGs are unable to attract resources in order to finance their missions effectively which is leading to their underperformance. Although traditional economic theory would predict that the decision to abandon production activity is based upon under performance, SHGs tend to continue providing their services despite their inability to attract adequate resources. Several factors may explain this fact - including the motivation of members, the feelings of social security provided by a sense of belonging to a group, feelings of appreciation and recognition from community members and the attractiveness of their social mission.

A second important relationship was indicated by examining the change in the year of registration. A unit change in registration had a significant positive effect on the expected changes in the number of economic empowerment activities. Once registered the self-help groups see themselves as legal associations and can hence carry out their activities formally. On the other hand, registration accords them recognition by their community, resource providers and other institutions. This recognition plays an important role in increasing their confidence.

Increases in management committee meetings had a positive effect on expected changes in the number of economic empowerment activities. To a lesser extent, members meetings (also known as general meetings) had the same effect. Meetings play an important role in decision making about what activities SHGs undertake. Management committee meetings help guide future expected activities and investments. This is because management committees are specialized bodies within the self-help group with a mandate to oversee overall resource mobilization, as well as implement and evaluate the self-help group activities. Self-help groups with a management committee structure therefore tended to fare better with economic empowerment activities.

Conversely, increases in the number of challenges facing the SHG have a negative effect on expected changes in the number of economic empowerment activities. Challenges, as illustrated in Table 13, may be internal or external. There are challenges that organizations have control over and those that they do not. Several SHGs seemed to be facing many challenges they are not in control of and this is costing them considerable energy and diminishing their effectiveness as service providers. An example is those SHGs that had 
legal disputes with each other. Since the SHGs are not considered to be legal entities, their cases may not be taken up by industrial tribunals and hence they may be forced to deal with the complexities surrounding their legalities before court proceedings may begin. Such disputes may start with simple issues but raise a plethora of challenges that take a great toll on productivity, time and energy. Legal challenges are just one example; there are many other challenges facing the SHGs in terms of resources and relationships.

Having fewer networks is correlated with negative effects on the expected changes in the number of economic empowerment activities. This fact is evident as participation in networks offers many benefits to organizations. Networking is an important function of human capital. Pursued well it can lead to the betterment of entrepreneurial abilities, the creation of useful social capital, the acquiring of useful information and improvements in the learning ability of SHG's (e.g. about industry practices) which in turn enhances organizational capabilities through the imitation of best practice (Lengyel 2002). Networking has five important advantages, which include gap identification, experiential sharing and learning, enhancing resource mobilization abilities, learning from the best practices of peers and the identification of useful social capital. The fact that a majority of self-help groups were not engaged in networking therefore explains their significantly reduced performance.

Lastly, positive unit changes in membership and village outreach increase the number of economic empowerment activities. Self-help groups with more members have to be more creative in order to empower both their members and the community and are expected to create economic activities commensurate to their size and mission. Correspondingly, outreach to different villages also calls for SHGs to be creative. This is because there are micro variations with different villages which requires the creative localization of interventions.

\section{CONCLUSIONS}

The Harambee spirit in Kenya, if harnessed well, could have an important role in reinforcing the third sector because of its autonomy, self help and strong volunteering dimension. It could help by building-up socio-economic institutions that are neither investor-owned (profit making) nor public agencies (the state), but which emerge directly as a result of pressing local needs. The Harambee movement has specific features of the third sector and is in accordance with Kenyan traditions and the national context.

Keeping in mind that the Harambee spirit is already accredited with 
furthering social, environmental, economic and cultural objectives through voluntary efforts, it certainly represents a good foundation for social enterprises and ultimately a vibrant third sector. Despite its weaknesses over the years, the Harambee self-help movement is still considered to be a vehicle for social change with which the under-represented can be given a voice and fragmented communities can be connected and enabled to contribute to problem solving.

The Harambee self-help groups in Kenya exemplify an indigenous model of social enterprise. These groups have survived challenges and overcome limitations over time while struggling to evolve and gain stability. Some of their restrictions have included the limiting nature of the current type of legislative regime, uncertainties over funding, lack of effective resource mobilization abilities, factional disputes in relation to group and resource control, opportunism, the inability to access important information and an overbearing bureaucracy. Other challenges emanating from their membership structure include the problems of free riding, transparency and accountability.

Though they face myriad challenges, the self-help groups seem to be playing the role of social enterprises in humble ways. As can be seen from the data presented in this paper, resources are collected from within the group, the public, grant-making organizations, their own organizational investments and from government funding and other sources. According to Borzaga and Defourny (2001), social enterprises not only enhance social services but they do it innovatively by blending public and private resources. Social enterprises have both an entrepreneurial dynamic and a social aim; the Kenyan self-help groups also have these attributes.

Kenya as a country could benefit from the experiences of European countries which have established social enterprise laws for their community-based enterprises. Accordingly, an appropriate legal regime for the Harambee selfhelp groups would go a long way towards shaping these groups into effective tools for addressing poverty at the grassroots level and enhance their ability to deal with other problems which affect Kenyan communities. Building on the existing strengths of the self-help groups would help considerably to strengthen their social enterprise dimensions, and ultimately improve the third sector in Kenya.

Accordingly, the community development work of the self-helps represents an empowerment approach which requires both deductive and inductive learning on the one hand, and knowledge accumulation on the other. This learning helps increase their internal capability to pursue a broad set of activities. One important area where self-help organizations can develop is in their networking with the public, market and the local and international 
community. By doing so, they can improve the effectiveness of their work and improve their community-based human development and social economic impacts.

\section{REFERENCES}

Barkan, J. D. - Holmquist, F. (1989), Peasant relationships and the social base of self help in Kenya. World Politics, 41(3), 359-380.

Bhatliwala, S. (2002), Grassroots Movement as Transnational Actors: Implications for Global Civil Society. Voluntas, 13 (4), 393 to 409.

Borzaga C. - Defourny J. (2001), The emergency of Social Enterprise. London and New York. Routledge Taylor and Francis Group.

Borzaga, C. -Nogales, R. - Galera, G. (2008), Social Enterprise a New Model for Poverty Reduction and Employment Generation. Bratislava: EMES and UNDP.

Branch, D. - Cheeseman, N. (2007), Democratization, Sequencing and state failure in Africa: Lessons from Kenya. . African Affairs., 108(430), 1-26.

Bruin, J. (2006), Command to compute new test. Retrieved 9 23, 2012, from UCLA Academic Technology Services: http://www.ats.ucla.edu/stat/stata/ado/analysis/.

Chelogoy, M. - Anyango, H. - Odembo, E. (2004), Introduction to Non Profit Sector in Kenya. Nairobi: Ufadhili Trust.

Coppock, D. L. - Desta, S. et al., (2006), Women's Groups in Arid Northern Kenya: Origins, Governance, and Roles in Poverty Reduction. Nairobi: International Livestock Research Institute (ILRI).

Godfrey, E. M. - Mutiso, G. C. (1973), The political economy of self-help: Kenya's Harambee Institutes of Technology. . Nairobi: Institute of Development Studies, University of Nairobi.

Hamer, J. H. (1981), Preconditions and Limits in the Formation of Associations: The Self-Help and Cooperative Movement in Subsaharan Africa. African Studies Review, 24(1), 113-132.

Hindu Press International (2003), Kenyan motto controversial to some. Retrieved January 14, 2012, from Hindu Press International: https://www.hinduismtoday. com/blogs-news/hindu-press-international/kenyan-national-motto-controversialto-some/print,3084.html

Kanyinga, K. - Mitullah, W. (2007), The Non Profit Sector in Kenya: What we Know and What we do Not Know. Nairobi: Institute of Development Studies, Nairobi University.

Koinonia Community (2006), Projects and Activities for Street children in Nairobi. Nairobi: Kolbe Press.

Long, J. S. (1997), Regression models for limited and dependent variables. Carlifonia: Sage Publications.

Male, D. K. (1976), Influence of Government Patronage on Grassroots Harambee Self Help in Kenya. . The Fourth World Congress of Rural Sociology. Torun, Poland. 
Martin, H. (1990), The Harambee Self-Help movement in Kenya . London: London School of Economics.

Matanga, F. K. (2000), Civil Society and Politics in Africa: The Case of Kenya. Conference on Third Sector for What and For Whom? . Dublin, Ireland: Trinity College.

Mbithi, P. M., \& Rasmusson, R. (1977), Self Reliance in Kenya, the Case of Harambee. Uppsala: Scandinavian Institute of African Studies.

Meyer W. and Zucker L. (1989), Permanently Failing Organizations. New York. Sage Publications

Ngau, P. M. (1987), The experience of the Harambee Self-Help in Kenya. Economic Development and Cultural Change, 35(3), 523-538.

Nyaga, M. (1986), Against Many Odds: The Dilemmas of Women's Self-Help Groups in Mbeere, Kenya. Journal of the International African Institute, 56(2), 210-228.

Ochanda, R. M., Akinyi, V. A. - Mungai, M. N. (2009), Human Trafficking and Commercial Sexual Exploitation of Women and Children in East Africa. Nairobi: Kerosip Printers.

Ochanda, R. M., Berhanu, G. - Wamalwa, H. (2011), Effectiveness of street youth integration in East Africa. Post Modern Openings, 6, 57-75.

Ombudo, O. (1986), Harambee: The origin and use. Nairobi: Acedemic Publishers.

Ouma, S. J. (1980), A history of the Cooperative Movement in Kenya. Nairobi: Bookwishe Ltd.

Porter, M. E. (1985), Competitive Advantage. New York: Free Press.

Republic of Kenya. (1964a), National Community Development Plan. Nairobi: Government Printers.

Republic of Kenya. (1965), Sessional Paper 10 of 1965. Nairobi: Government Printers.

Republic of Kenya. (1979), Development plan 1979 to 1983. Nairobi: Government Printer.

Republic of Kenya. (2009a), The draft national policy on community development. Nairobi: Ministry of Gender, Children and Social Development.

Republic of Kenya. (2009i), Draft five years strategic plan. Nairobi: Ministry of Youth Affairs.

Republic of Kenya. (2010), The constitution of Kenya. Nairobi: Government Printers.

Sobania, N. (2003), Culture and Customs of Kenya. USA. Greenwood Publishing Group.

Transparency International. (2003), Harambee: patronage, politics and disregard of law. Nairobi: Transparency International December issue 10.

Transparency International Kenya. (2001), Harambee: Pooling together or pulling apart? Nairobi: Transparency International Kenya.

UNDP. (1990), Human Development Report 1990. New York: Oxford University Press.

Waiguru, A. (2002), Corruption and Patronage Politics: The Case of Harambee in Kenya. Workshop on measuring Corruption. Brisbane, Australia.

Wallis, M. (1976), Community development in Kenya: Some current issues. 
Development Journal, 11(3), 192-198.

Wallis, M. (1990), District planning and local government in Kenya. Public Administration and Development, 10(4), 437-452.

Wallis, M. A. (1980), Bureaucrats, politicians, and Harambee. Manchester City: University of Manchester.

Winans, E. V. - Haugerud, A. (1977), Rural Self Help in Kenya: Harambee Movement. Human Organization, 36(4), 334-351.

Lengyel G. (2002), Social Capital and Entrepreneurial Success: Hungarian Small Entreprises in 1993 to 1996 in V. Bonnel, T. B. Golds (eds), The New Entrepreneurs of Europe and Asia. Sharpe Armonk P. 256-277

Long J. S. (1997), Regression models for limited and limited dependent variables. Thousand Oaks. Sage Publications. 